\title{
Opportunistic Germination Behaviour of Gypsophila (Caryophyllaceae) in Two Priority Habitats from Semi-arid Mediterranean Steppes
}

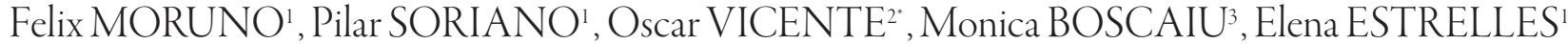 \\ ${ }^{1}$ Universitat de València, ICBiBE-JardíBotànic,C/Quart80,46008,Valencia, Spain; felixmoruno@uv.es; elena.estrelles@uv.es; pilar.soriano@uv.es \\ ${ }^{2}$ Universitat Politécnica de València, Instituto de Biología Molecular y Celular de Plantas (UPV-CSIC), CPI edificio \\ 8E, Camino de Veras/n, 46022, Valencia, Spain; ovicente@ibmcp.upv.es (correspondingauthor) \\ ${ }^{3}$ Universitat Politécnica de València, Instituto Agroforestal Mediterráneo (UPV), CPI edificio \\ 8E, Camino de Veras/n,46022-Valencia, Spain; mobosnea@eaf.upv.es
}

\begin{abstract}
Gypsophila tomentosa and G. struthium are closely related species, characteristic of two European priority habitats, salt and gypsum inland steppes, respectively. Germination strategies of the two taxa were investigated in plants from two nearby populations, growing under the same climatic conditions but on different types of soil, and belonging to different plant communities. Their germination patterns were studied at five constant temperatures in darkness: $5^{\circ} \mathrm{C}, 10^{\circ} \mathrm{C}, 15^{\circ} \mathrm{C}, 20^{\circ} \mathrm{C}$ and $25^{\circ} \mathrm{C}$, and the base temperature and the thermal time requirement were calculated. As the distribution area of both species is subjected to a Mediterranean continental climate with significant differences between day and night, the possible preferences for an alternating temperature regime $\left(25 / 10^{\circ} \mathrm{C}\right)$ were contrasted, as well as the influence of cold stratification and freezing. The effects on seed germination of light at constant $20^{\circ} \mathrm{C}$ and a $12 / 12 \mathrm{~h}$ photoperiod were also compared in the two species. The main conclusions of the work are the similarity of behaviour of both species, with an absence of seed dormancy, their opportunistic germination strategy, and water availability as the principal limitation to seed germination and plant establishment. The base temperature and thermal time indicate higher competitiveness of $G$. struthium at low temperatures, but seed germination of $G$. tomentosa is the most efficient at temperatures higher than $13.3^{\circ} \mathrm{C}$. Optimal temperature and illumination conditions for nursery propagation depend on the species. The high viability of seeds observed after freezing prove the orthodox character of these seeds, providing additional information for long term seed conservation procedures.
\end{abstract}

Keywwords: endemics, Gypsophila struthium, Gypsophila tomentosa, gypsum habitats, plant conservation, plant propagation, seed germination

\section{Introduction}

Salt and gypsum steppes have been classified as priority habitats for conservation under the code numbers ${ }^{*} 1510$ and ${ }^{*} 1520$, respectively, of the Council Directive $92 / 43 /$ EEC (European Commission, 1992), and are considered among the most threatened ecosystems in Europe (Pueyo et al., 2007; Silliman et al., 2009).

These two types of habitats have been the subject of different studies (Escudero et al., 1997; Khan et al., 2000; Mota et al., 2004; Pueyo et al., 2007; Silliman et al., 2009); however, as for other ecosystems, our knowledge concerning the reproductive ecology and propagation of most species of the threatened flora is still very limited. The establishment and implementation of conservation plans for priority habitats require a deep knowledge of plant reproduction and propagation of species growing in threatened communities.

Germination patterns are relevant to understand the ecological equilibrium and community maintenance in natural habitats (Espinar et al., 2005) and also to develop reliable protocols for nursery propagation. Growers of native species used in revegetation could then use these protocols to provide plants with adequate genetic diversity for restoration programmes of natural populations (Rogers, 2004; Rose et al., 1998).

The Native Plant Working Group (2000) identified the unpredictable germination of wild seeds as one of the major limitations for the use of several native plants in revegetation projects, and the development of improved propagation techniques as one of the future needs.

During the last thirty years, germination has been an important research topic in plant conservation biology (Soule and Kohm, 1989). Despite the large number of publications in this field, research on optimal germination conditions for native wild species is still required today. According to Randriatafika et al. (2007), germination studies represent an essential part of biodiversity conservation and recovery strategies, as they can lead to the improvement of propagation techniques.

Two Gypsophila species, closely related taxonomically but growing in different habitats, were selected for this 
study, which aimed to contribute to the conservation and restoration programmes developed in the locality of Villena (Alicante, Spain) by the regional government of the Valencian Community. Gypsophila struthium L. is characteristic of gypsum communities of Helianthemo thibaudiiTeucrietum libanitidis Rivas Goday and Rigual in Rivas Goday, Borja, Monasterio, Galiano, Rigual and RivasMartínez 1957 corr. Díez Garretas, Fernández-González and Asensi 1996 nom. mut., whereas Gypsophila tomentosa Loefl. lives at the border of subsided areas, where the soils are more humid and saline; here the dominant vegetation is Limonio-delicatuli-Gypsophiletum tomentosae PeinadoLorca and Martínez-Parras, 1982.

These two plant communities grow in neighbouring areas. The populations of $G$. struthium were included in the Valencian Plant Microreserves Network in 1999 as an in situ conservation measure (Laguna, 2001). Both species are also included in the ex situ conservation programme of the 'Germplasm Bank of the Valencian Wild Flora' located in the Botanical Garden of the University of Valencia (Estrelles et al., 2004).

This territory, with about $350 \mathrm{~mm}$ of annual rainfall, is classified as semi-arid under a Mediterranean pluviseasonal-oceanic climate, according to the Bioclimatic Classification System (Rivas-Martínez and Rivas-Sáenz, 2009).

The present study attempts to assess the propagation of native Gypsophila for use in restoration of natural habitats disturbed by diverse human actions. Our main objective was to determine germination responses in these two species, to improve propagation methods by optimizing the seed used. The specific questions addressed were: (a) Do these species show any dormancy level? (b) Are temperature and light the factors controlling germination in these species from Mediterranean semiarid climate? (c) Have the two species of Gypsophila, growing in habitats with different soil characteristics but under the same climatic conditions, different germination strategies? (d) Do winter temperatures have any influence on seed responses? (e) Which are the optimal temperature and photoperiod conditions to optimize plant production for restoration activities?

\section{Materials and methods}

Origin of seeds

The seeds used in this study were collected from the Valley of Villena in the Basin of the Vinalopó River, in the Alicantine sector of the biogeographic province Murciano-Almeriense (SE Spain). Seeds of Gypsophila struthium were collected from the flora microreserve 'Los Cabecicos', (UTM 30SXH8379). Seeds of Gypsohila tomentosa were sampled from 'Las Salinas de la Redonda', (UTM 30SXH8080). Mature dry seeds were stored at $4^{\circ} \mathrm{C}$, immediately after collection, for one month before used in the experiments.
Germination experiments were completed after 15 days when no additional seeds had germinated for $5 \mathrm{~d}$. Four replications of 25 seed were placed on $0.6 \%$ agar, in $55 \mathrm{~mm}$ diameter Petri dishes. The number of germinated seeds was counted every two days, and germinated seeds were removed. Final germination percentage and mean time to germination (MTG) were determined according to Brenchley and Probert (1998).

\section{Light and temperature regime influence}

The germination responses at constant $\left(20^{\circ} \mathrm{C}\right)$ and fluctuating day/night $\left(25 / 10^{\circ} \mathrm{C}\right)$ temperatures were checked under two different light regimes, total darkness and 12 $\mathrm{h}$ photoperiod using daylight fluorescent illumination $\left(100 \mu \mathrm{E} \mathrm{m}^{-2} \mathrm{~s}^{-1}\right)$. The alternating temperature regime was selected according to the continental local climate. Seed germination in darkness at $5^{\circ} \mathrm{C}, 10^{\circ} \mathrm{C}, 15^{\circ} \mathrm{C}, 20^{\circ} \mathrm{C}$ and $25^{\circ} \mathrm{C}$ was checked under green safe light provided by two green luminescent lamps (Philips TL-D 18W/17) supplemented with a green filter (Roscolux ref. $n^{\circ}$ 90).

\section{Effect of a cold stratification period}

A stratification treatment was carried out by maintaining seeds of both species in a germination chamber at $5^{\circ} \mathrm{C}$ in darkness for 45 days, previous to germination tests at $15^{\circ} \mathrm{C}$, also in the dark. The temperature of $5^{\circ} \mathrm{C}$ was selected as pre-treatment since similar average temperatures are recorded at the sampling site at least three months a year (December, January and February).

\section{Effect of a freezing period}

The germination capacity of seeds stored for two years at $-25^{\circ} \mathrm{C}$ (after desiccation with silica gel) was tested at $15^{\circ} \mathrm{C}$ in darkness. This low temperature corresponds to the winter minimum in the natural area and the experiment provides additional information to check seed banking procedures.

\section{Data analysis}

Germination percentages were expressed as mean \pm SE. The obtained germination percentages were statistically compiled in box plot graphics where the minimum, median and maximum values were shown; the interquartile ranges are represented as grey bars, including $50 \%$ of the data values. The rate of germination was expressed as the mean time to germination (MTG) according to Brenchley and Probert (1998). The base temperature $\left(\mathrm{T}_{\mathrm{b}}\right)$ was also calculated for each species by back extrapolation (GarciaHuidobro et al., 1982), as the thermal time requirement (Trudgill, 1995) in order to compare thermal responses.

Germination percentages were arcsine transformed (Zar, 1984) and the variance was analysed to compare the conditions used. Analysis of variance (Sokal and Rohlf, 1995) was applied to determine if significant differences were present among means $(\mathrm{p}<0.05)$. A post-hoc Tukey 
20

test was used to estimate least significant range between means obtained at constant temperatures in order to determine the optimal response. All statistical methods were performed using SPSS, version 16.0.

\section{Results and discussion}

Final germination percentages and the mean time to germination (MTG) obtained under the studied conditions are compiled in Tab. 1 and Fig. 1. In G. struthium the effect of light is significant, but not the variation of temperature or the interaction of both factors, as shown in Tab. 2. At $25 / 10^{\circ} \mathrm{C}$, germination in darkness was significantly higher, but at $20^{\circ} \mathrm{C}$, seed germination of $G$. struthium under a $12 \mathrm{~h}$ light photoperiod did not differ significantly from germination in the dark. There were no statistically significant differences between the constant and the alternating temperature regimes applied.

On the contrary, germination in $G$. tomentosa was not affected by the light condition applied, as the seeds germinated equally well in light and darkness, whereas the temperature regime had a significant effect, as shown by two way ANOVA (Tab. 3), with better germination detected for constant temperature (Tab. 1). The interaction between temperature regime and light on final germination was also significant, indicating that the germination response to light depended on the constant or alternating temperature regime used. Germination under a constant regime of temperature showed identical response to light and darkness; the highest percentage was registered at $25 / 10^{\circ} \mathrm{C}$ under a $12 \mathrm{~h}$ photoperiod. Definitely, seed germination in $G$. tomentosa was significantly affected by the temperature regime and the interaction with illumination (Tab. 3).

The minimum, the median and the maximum values, as well as the interquartile range for germination tests performed in darkness, are shown in Fig. 1. In the dark, over $90 \%$ of the seeds of $G$. tomentosa germinated at all temperatures tested, with a maximum $(100 \%)$ at $20^{\circ} \mathrm{C}$ (see Tab. 1). When comparing the two species, slightly lower germination percentages were determined for G. struthium under the same conditions, with the best response at $15^{\circ} \mathrm{C}$ and $10 / 25^{\circ} \mathrm{C}\left(93 \%\right.$ and $94 \%$, respectively). At $10^{\circ} \mathrm{C}$, germination was clearly lower than in G. tomentosa $(76 \%$ vs. 93\%, Tab. 1). Optimal values of MTG were obtained at $20^{\circ} \mathrm{C}$ and $25^{\circ} \mathrm{C}$ for both species.

Germination percentages of seeds after stratification or freezing treatments were not significantly different to controls at the same temperature $(G$. struthium $\mathrm{F}=0.243$, $\mathrm{p}=0.790 ;$ G. tomentosa $\mathrm{F}=0.568, \mathrm{p}=0.586)$. Seeds after two years of storage in the seed bank did not lose viability when compared to controls. When comparing germination velocities, G. struthium showed stimulation after cold and freezing pretreatments, with shorter MTG values than those of the control at $15^{\circ} \mathrm{C}($ G. struthium $\mathrm{F}=14.424, \mathrm{p}=$ 0.002; G. tomentosa $\mathrm{F}=0.314, \mathrm{p}=0.738$ ).

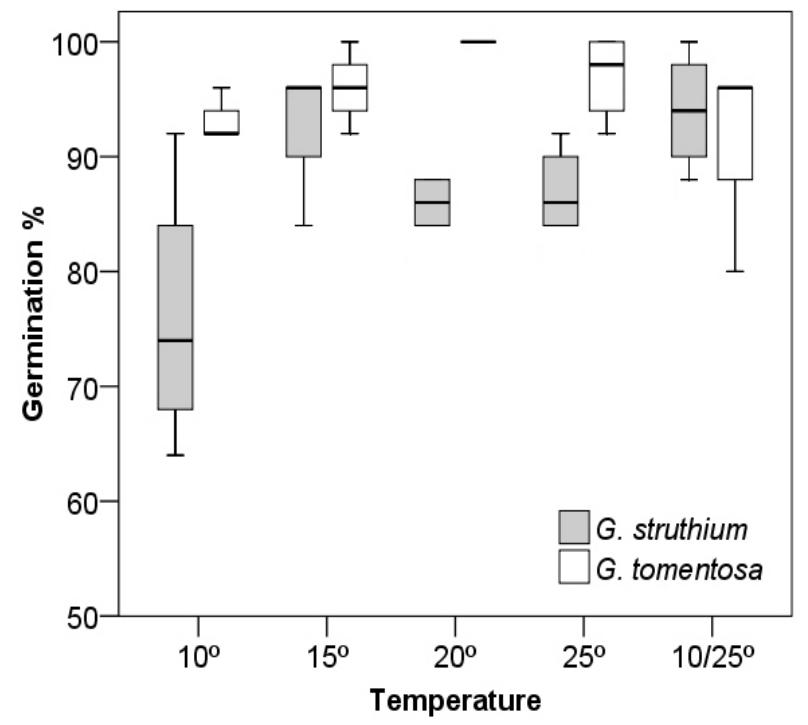

Fig. 1. The minimum, median, and maximum values and the interquartile range for germination tests completed in darkness for seeds of Gypsohila struthium and G. tomentosa

Tab. 1. Final germination percentages (mean \pm standard deviation), and mean time to germination (MTG), obtained under the indicated temperature and light conditions, for seeds of Gypsophila struthium and G. tomentosa after 15 days of incubation. Values in a column followed by the same letter are not significantly different. Asterisks in the last column indicate statistically significant differences of germination percentages between the two species $(\mathrm{p}<0.05)$

\begin{tabular}{|c|c|c|c|c|c|c|}
\hline \multirow[t]{2}{*}{$\mathrm{T}^{\mathrm{a}} /$ light } & \multirow[t]{2}{*}{ Pretreatment } & \multicolumn{2}{|c|}{ G. struthium } & \multicolumn{2}{|c|}{ G. tomentosa } & \multirow{2}{*}{$\begin{array}{l}\text { Interspecific } \\
\text { differences }\end{array}$} \\
\hline & & $\%$ & MTG & $\%$ & MTG & \\
\hline $5^{\circ} \mathrm{C} /$ darkness & - & 0 & - & 0 & - & - \\
\hline $10^{\circ} \mathrm{C} /$ darkness & - & $76 \pm 5.9^{b}$ & $6.9^{c}$ & $93 \pm 1.0^{\mathrm{ab}}$ & $9.1^{\mathrm{d}}$ & * \\
\hline $15^{\circ} \mathrm{C} /$ darkness & - & $93 \pm 3.0^{\mathrm{a}}$ & $4.5^{\mathrm{ab}}$ & $96 \pm 1.6^{\mathrm{ab}}$ & $4.4^{\mathrm{c}}$ & - \\
\hline $20^{\circ} \mathrm{C} /$ darkness & - & $86 \pm 1.2^{\mathrm{ab}}$ & $3.7^{\mathrm{a}}$ & $100 \pm 0.0^{\mathrm{a}}$ & $2.5^{\mathrm{a}}$ & * \\
\hline $25^{\circ} \mathrm{C} /$ darkness & - & $87 \pm 1.9^{\mathrm{ab}}$ & $3.8^{\mathrm{a}}$ & $97 \pm 1.9^{\mathrm{ab}}$ & $2.5^{\mathrm{a}}$ & * \\
\hline $20^{\circ} \mathrm{C} / 12 \mathrm{~h}$ light & - & $82 \pm 2.6^{\mathrm{ab}}$ & $3.2^{\mathrm{a}}$ & $99 \pm 1.0^{\mathrm{a}}$ & $2.5^{\mathrm{a}}$ & * \\
\hline $25 / 10^{\circ} \mathrm{C} / 12 \mathrm{~h}$ light & - & $75 \pm 3.0^{\mathrm{b}}$ & $6.4^{\mathrm{b}}$ & $98 \pm 2.0^{\mathrm{ab}}$ & $3.7^{\mathrm{b}}$ & * \\
\hline $25 / 10^{\circ} \mathrm{C} /$ darkness & - & $94 \pm 2.6^{a}$ & $5.0^{\mathrm{b}}$ & $92 \pm 4.0^{\mathrm{b}}$ & $3.4^{\mathrm{b}}$ & - \\
\hline $15^{\circ} \mathrm{C} /$ darkness & $1 \mathrm{~m} / 5^{\circ} \mathrm{C}$ & $91 \pm 2.5^{a}$ & $3.8^{\mathrm{a}}$ & $94 \pm 1.4^{\mathrm{ab}}$ & $4.4^{\mathrm{c}}$ & - \\
\hline $15^{\circ} \mathrm{C} /$ darkness & $2 \mathrm{y} /-25^{\circ} \mathrm{C}$ & $93 \pm 1.7^{a}$ & $3.7^{\mathrm{a}}$ & $96 \pm 1.4^{\mathrm{ab}}$ & $4.3^{c}$ & - \\
\hline
\end{tabular}


Tab. 2. Two-way ANOVA analysis of the effects of temperature regime, light and their interactions on seed germination in Gypsophila strutbium $(\alpha=0.05)$

\begin{tabular}{cccccc}
\hline Source of variance & $\begin{array}{c}\text { Sum of } \\
\text { squares }\end{array}$ & df & $\begin{array}{c}\text { Mean } \\
\text { Square }\end{array}$ & $\begin{array}{c}\mathrm{F} \\
\text { ratio }\end{array}$ & $\begin{array}{c}\mathrm{p} \\
\text { value }\end{array}$ \\
\hline Temperature regime & 0.007 & 1 & 0.007 & 0.864 & 0.371 \\
Light & 0.132 & 1 & 0.132 & 15.510 & $0.020^{*}$ \\
Temperature x light & 0.067 & 1 & 0.067 & 7.836 & 0.160 \\
\hline Error & 0.102 & 12 & 0.009 & & \\
\hline
\end{tabular}

Tab. 3. Two-way ANOVA analysis of the effects of temperature regime, light and their interactions on seed germination of Gypsophila tomentosa $(\alpha=0.05)$

\begin{tabular}{cccccc}
\hline Source of variance & $\begin{array}{c}\text { Sum of } \\
\text { squares }\end{array}$ & df & $\begin{array}{c}\text { Mean } \\
\text { Square }\end{array}$ & $\begin{array}{c}\mathrm{F} \\
\text { ratio }\end{array}$ & $\begin{array}{c}\mathrm{P} \\
\text { value }\end{array}$ \\
\hline Temperature regime & 0.083 & 1 & 0.083 & 6.941 & $0.022^{*}$ \\
Light & 0.021 & 1 & 0.021 & 1.754 & 0.210 \\
Temperature x light & 0.060 & 1 & 0.060 & 5.037 & $0.044^{*}$ \\
\hline Error & 0.144 & 12 & 0.012 & & \\
\hline
\end{tabular}

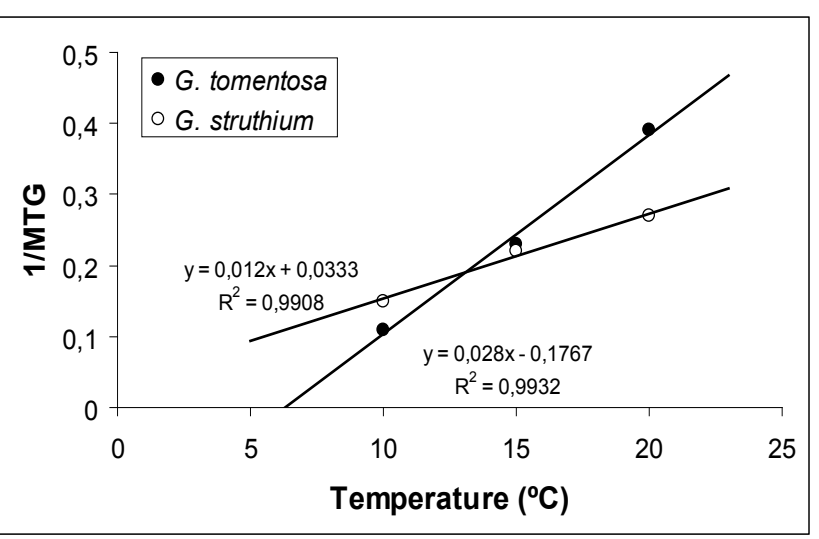

Fig. 2. Linear regresion of germination rates related to the temperature in darkness for Gypsophila struthium $(\bullet)$ and G. tomentosa (o)

The linear regression of germination rates at the different constant temperatures tested (Fig. 2) showed $\mathrm{a} \mathrm{T}_{\mathrm{b}}$ of $-2.8^{\circ} \mathrm{C}$ for $G$. struthium and of $6.3^{\circ} \mathrm{C}$ for $G$. tomentosa. The point of intersection of the lines for each species is at $13.3^{\circ} \mathrm{C}$. The calculated thermal time for $G$. struthium is $83.3^{\circ} \mathrm{C}$ day and $35.7^{\circ} \mathrm{C}$ day for $G$. tomentosa.

Seeds of both studied species show an orthodox behaviour, as seed viability remains high after desiccation to a low relative humidity, or after storage under freezing conditions for two years in the seed bank.

The high germination capacity of seeds incubated directly on agar plates at different temperatures, shortly after collection, already suggested the absence of dormancy in the two species. Seeds of $G$. struthium and $G$. tomentosa are mature at the end of the summer, after the Mediterranean typical summer stress has ceased and the absence of primary dormancy permits germination during autumn rains. In addition, low temperatures, simulating the pass of winter, did not cause any type of secondary dormancy. Thus, seeds that did not germinate in autumn are ready to germinate immediately when water resources are available and the temperature is adequate. These aspects are relevant for seed banking and also to establish in situ conservation plans for these endemic and threatened species or their habitats, both of special interest in Europe. The significant differences observed in germination responses were not too divergent. Even the worst germination percentage, with a $73 \%$ obtained at $10^{\circ} \mathrm{C}$ in $G$. struthium, is acceptable. In fact, seeds of the two tested species reached high germination percentages under all the different temperatures and photoperiods used. This indicates a limited influence on seed germination of environmental conditions other than water availability for both, G. struthium and $G$. tomentosa.

The optimal temperature that we recommend for nursery protocols is $15^{\circ} \mathrm{C}$ for $G$. struthium, whereas for $G$. tomentosa could be higher, $20^{\circ} \mathrm{C}$ to $25^{\circ} \mathrm{C}$. These results are in agreement with previously published data: low temperatures were found to be optimal for germination of all gypsohytes studied by Escudero et al. (1997), except Helianthemum squamatum, which has hard seeds. On the contrary, many salt-marsh plants tend to require a relatively higher temperature for seed germination (Khan et al., 2000).

Germination rate, as other developmental parameters, shows a linear correlation with temperature in a wide range up to the thermal optima, $\mathrm{T}_{\mathrm{o}}$ (Trudgill, 1995). The values obtained for thermal times show that $G$. tomentosa seeds increase rapidly their response when temperature goes up, whereas $G$. struthium has better response at lower temperatures, up to $13.3^{\circ} \mathrm{C}$. This different behaviour could partly explain why $G$. struthium is a wider distributed plant, and $G$. tomentosa has very localised populations in this region, characterized by low temperatures.

Regarding the light factor, in the two species high percentages of germination were obtained under both conditions tested, indicating that light is not a restrictive factor for their germination. This behaviour is not general since light is normally an important ecological factor, but our findings are in agreement with the observations of Khan and Gulzar (2003) for some perennial halophytic grasses; these authors also indicated that the responses to light differ depending on the species. There are species whose seeds can remain several years dormant in the dark, but germinate in a short time in the presence of light and, on the contrary, seeds of other species germinate only in absolute darkness. Another common characteristic of the studied species is that under optimal conditions their seeds germinated almost quantitatively within a few days. The high germination percentages and faster germination rates observed under the studied range of temperatures and the different light regimes, suggest an opportunistic germination strategy for both species. Species that live in xeric areas germinate under less restrictive temperature 
22

conditions. Under extreme drought conditions, with very low amounts of rain, these species have developed a different strategy affecting the number of seeds "ready to germinate" after a rainfall, and probably seedling drought tolerance. Opportunistic germination is one of the most common strategies in desert areas, arid sites and steppes, including the Mediterranean region.

In this situation, seedling establishment in natural habitats is not limited by temperature but by water availability, so that seed germination depends mainly on rainfall rather than on other environmental factors. These species achieve full germination within a short period, at a wide range of temperatures as well as under light or darkness. Their seeds must germinate rapidly with any hydric provision, maybe the only one during the year, to complete the biological cycle.

The same behaviour has been found in species or populations from drylands and from variable or unpredictable environments (Escudero et al., 2002; Estrelles et al., 2010; Gutterman, 2001). This opportunistic germination strategy is shared with species from desert areas such as Blepharis persica (Gutterman, 1972), Launaea arborescens (Schütz and Milberg, 1997), and Schismus arabicus (Gutterman, 2001), or with Eucalyptus species from semi-arid habitats (Schütz et al., 2002). This ecological trait of germination and rapid early growth when water is available is always related to scarce rainfall at the site of seed origin.

\section{Conclusions}

In conclusion, although G. struthium and G. tomentosa have different ecological traits, this does not seem to be due to intrinsic differences in their germination response. Germination patterns on agar plates, in the absence of natural stressful conditions, are similar for both taxa under different temperature and light levels, probably as it should be expected considering the close genetic relationship of the two species. Both species show high adaptation to their specific habitats. Their germination behaviour makes them highly competitive in colonizing available and adequate soils. This consideration agrees with Mota et al. (2004) who found that G. struthium has very high cover rate on restoration of quarries in the SE Iberian Peninsula, even higher than in unaltered areas. Finally, we recommend further studies of other factors present at their respective natural habitats, as osmotic or salinity stress, to complete the understanding of germination responses and the seedlings establishment in relation to the different distribution and ecology of these taxa in the wild.

\section{Acknowledgements}

The experiments were conducted at the Botanical Garden of the University of Valencia and were co-financed by the European Union Interreg Project GENMEDOC (Création d'un reseau de centres de conservation du matériel génétique de la flore des régions méditerranéennes de l'espace MEDOCC), project number 2003-03-4.1-E-060, and Generalitat Valenciana (Consellería de Medio Ambiente, Agua, Urbanismo y Vivienda).

\section{References}

Brenchley JL, Probert RJ (1998). Seed germination responses to some environmental factors in the sea grass Zoostera capricorni from eastern Australia. Aquat Bot 62:177-188.

Escudero A, Carnes LF, Pérez-García F (1997). Seed germination of gypsophytes and gypsovags in semi-arid central Spain. J Arid Environ 36:487-497.

Escudero A, Pérez-García F, Luzuriaga AL (2002). Effects of light, temperature and population variability on the germination of seven Spanish pines. Seed Sci Res 12:261271.

Espinar JL, García LV, Clemente L (2005). Seed storage conditions change the germination pattern of clonal growth plants in Mediterranean salt marshes. Am J Bot 92:10941101.

Estrelles E, Fuentes N, Prieto J, Boscaiu M, Ballesteros D, Ibars AM (2004). Threatened Valencian Flora: Initiatives for its conservation, p. 857-868. In: Smith RD et al. (Eds.). Seed Conservation: Turning science into practice. Royal Botanical Garden Kew, London.

Estrelles E, Güemes J, Riera J, Boscaiu M, Ibars AM, Costa M (2010). Seed germination behaviour in Sideritis from different Iberian habitats. Not Bot Hort Agrobot Cluj 38(1):9-13.

European Commission (1992). Council Directive 92/43/EEC of 21 May 1992 on the conservation of natural habitats and of wild fauna and flora. Official Journal of the European Communities, series L 206:7-50.

García-Huidobro J, Monteith JL, Squire GR (1982). Time, temperature and germination of pearl millet. J Exp Bot $33: 288-296$

Gutterman Y (1972). Delayed seed dispersal and rapid germination as survival mechanisms of the desert plant Blepharis persica (Burm.) Kuntze. Oecologia 10:145-149.

Gutterman Y (2001). Phenotypic germination plasticity related to caryopsis size in Schismus arabicus. Seed Sci Res 11:173178

Khan MA, Gul B, Weber D (2000). Germination responses of Salicornia rubra to temperature and salinity. J Arid Environ 45:207-214.

Khan MA, Gulzar S (2003). Light, salinity, and temperature effects on the seed germination of perennial grasses. Am J Bot 90:131-134.

Laguna $\mathrm{E}$ (2001). The micro-reserves as a tool for conservation of threatened plants in Europe. 119 pp. Nature and Environment series 121. Council of Europe. Strasbourg.

Mota JF, Sola AJ, Jiménez-Sánchez ML, Pérez-García F, Merlo ME (2004) Gypsicolous flora, conservation and restoration of quarries in the southeast of the Iberian Peninsula. 


\section{Biodivers Conserv 13:1797-1808.}

Native Plant Working Group (2000). Native Plant Revegetation Guidelines for Alberta. H. Sinton-Gerling (ed.), Alberta Agriculture, Food and Rural Development and Alberta Environment. Edmonton, Alberta.

Pueyo Y, Alados CL, Maestro M, Komac B (2007). Gypsophile vegetation patterns under a range of soil properties induced by topographical position. Plant Ecol 189:301-311.

Randriatafika F, Rabenantoandro J, Rajoharison RA (2007). Analysis of seed germination of littoral forest native species in Southeastern Madagascar, p. 119-126. In: Ganzhorn JU, Goodman SM, Vincelette M (Eds.). Biodiversity, Ecology and Conservation of Littoral Ecosystems in Southeastern Madagascar, Tolagnaro (Fort Dauphin), SI/MAB Series 11, Smithsonian Institution, Washington, D.C.

Rivas-Martínez S, Rivas-Sáenz S (2009) Worldwide Bioclimatic Classification System. Phytosociological Research Center, Complutense University of Madrid (Spain). [cited 25 June 2010]. Available from URL: http://www.globalbioclimatics. org/

Rogers DL (2004). Genetic Erosion: No Longer Just an Agricultural Issue. Native Plants Journal 5:112-122.
Rose R, Chachulski CEC, Haase DL (1998). Propagation of Pacific Northwest Native Plants. Oregon State University Press. Corvallis, Oregon.

Silliman BR, Bertness MD, Grosholz E (2009). Human impacts on salt marshes: a global perspective. University of California Press, Berkeley.

Sokal RR, RohlfEJ (1995). Biometry. $3^{\text {rd }}$ Ed. CA. Freeman, San Francisco.

Soule ME, Kohm KA (1989). Research priorities for conservation biology. Society for Conservation Biology. Island Press. Washington D.C.

Schütz W, Milberg P (1997). Seed germination in Launaea arborescens: a continuously flowering semi-desert shrub. J Arid Environ 36:113-122.

Schütz W, Milberg P, Lamont BB (2002). Germination requirements and seedling responses to water availability and soil type in four eucalypt species. Acta Oecol 23:23-30.

Trudgill DL (1995). Why do tropical poikilothermic organisms tend to have higher threshold temperatures for development than temperate ones? Funct Ecol 9:136-137.

Zar JH (1984). Biostatistical Analysis (2nd edition). PrenticeHall, Englewood Cliffs, NJ. 